International Journal of Economics, Business and Management Research

Vol. 6, No.02; 2022

ISSN: $2456-7760$

\title{
Tourists' Satisfaction and Behavioral Intention in Eco-Tourism Sites of Sapa (Lao Cai Province)
}

\author{
Bui Thi Thanh Huong ${ }^{1}$, Lorna T. Grande ${ }^{2}$ \\ ${ }^{1}$ Thai Nguyen University of Economics \& Business Administration, Thai Nguyen University, \\ Tan Thinh ward, Thai Nguyen city, Thai Nguyen province, Vietnam \\ ${ }^{2}$ College of Business and accountancy, Central Philippine University, \\ Jaro, Iloilo City, 5000 Iloilo, Philippines
}

doi: 10.51505/ijebmr.2022.6215

URL: http://dx.doi.org/10.51505/ijebmr.2022.6215

\begin{abstract}
The main objective of the research was to determine the tourists' satisfaction and their behavioral intention to travel to eco-tourism destinations of Sapa for the Year 2020. The study's methodology used questionnaire which was designed with the purpose to describe the factors influencing tourists' satisfaction of the eco-tourism destinations of Sapa as perceived by respondents and determine the influence of tourist's satisfaction on tourist's behavioral intentions to pay more, to return, and to recommend to friends and relatives. The respondent of this study were domestic visitors who visited five ecotourism sites of Sapa (Lao Cai province). Because of Covid 19 epidemic's influence, the survey was conducted online in two months and 500 responses were received. The age of the respondents were from below 18 to over 60. To have the general view of the respondents, this study used Likert scales. All measurement items are based on a five-point Likert scale ( $1=$ strongly disagree; $5=$ strongly agree). The author used SPSS version 20 to run the data. Since the population was non propbalistic and data was not normally distributed, Non parametric test was used such as Mann-Whitney U-test for two groups (instead of t-test), Kruskal Wallis H-test for three or more groups and Spearman Rho. In addition, descriptive statistics, reliability test, factor analysis, were used in this study. The study recommended the following policy recommendations to improve the service of Eco tourism destinations in Sapa about Ecosystem health and cultural attraction; Amenities; Accommodation, food, people, safe and security and some other policy recommendations.
\end{abstract}

\section{Introduction}

Measuring tourists' satisfaction had become one of the well received topics for tourism researching in recent years (Chen \& Qiu, 2013). In addition, the connection between tourism's satisfaction and behavioural intention was supposed to be meaningful notice for both discoverers and scholars because this is the main reason to gain market share in the tourism industry. As a kind of tourism, ecotourism was proposed to meet the rising needs of essential tourism markets with high earnings, but also actively provide the preservation of natural and different values, biology, local culture and community development.

Currently there are many studies on ecotourism and tourism's satisfaction and behavioral intentionin the World such asthe relationship between the perceived value, satisfaction and 


\section{International Journal of Economics, Business and Management Research}

Vol. 6, No.02; 2022

ISSN: $2456-7760$

destination loyalty of community-based eco-tourists in Korea (Kim \& Park, 2017); The research on an example of Dapeng Bay National Scenic Area in service quality, destination image, service quality, satisfaction and behavioral intention (Lee, Pan \& Chung, 2019); The satisfaction of International tourists on Weh Island Indonesia with sea tourism, especially snorkeling and diving (Chan, 2016); The trip repeater's experience and intent at the visited port of call were influenced by the destination image (Toudert and Bringas-Rábago, 2016); Residents' intention to participate in ecotourism (Zhang \& Lei, 2012); In Vietnam, many authors are interested in perceptions of local people in tourism influence and their support for tourism development such as an example of Cuc Phuong national park (Pham \& Kayat, 2011); Also, Hương \& Huy checked local people' point of view and their taking part in development of tourism in Ba Be National Park (Hương \& Huy 2013). Khuong \& Luan examined key factors affecting the perceived value of tourists as well as their satisfaction with Cat Tien National Park. However, there are not many studies on relationship among tourists' perception, satisfaction and the evaluation of tourist in ecotourism in Vietnam (Khuong \& Luan, 2015).

In year 2020, the tourism industry was heavily affected by the NCovid 19. According to a report by the Department of Culture, Sports and Tourism of Lao Cai, the total number of visitors to Lao Cai reached over 2.2 million (down 57.9\% over the same period in 2019, reaching $86 \%$ of the plan).In which, international visitors reached 100,840 arrivals (down $87.5 \%$ over the same period in 2019); Domestic tourists reached over 2 million arrivals (down 52\% over the same period in 2019). Total tourism revenue reached 6,370 billion, (down $66.8 \%$ over the same period). Thus, in 2020, Lao Cai's strong industries such as commerce, tourism, accommodation, food and transportation services will all decrease compared to 2019 due to the great influence of the Covid-19 pandemic. all aspects of socio-economic life, especially tourism. Specifically: Service revenue in 2020 of accommodation decreased by $29.02 \%$ over the same period, food and beverage revenue decreased by $11.2 \%$, travel revenue decreased by $51.96 \%$.Plan No. 1749 was issued to launch "Vietnamese people travel to Vietnam" program (The Ministry of Culture, Sports and Tourism, 2020). The program duration was 6 months (from June 1 to December).

The main activities which were mentioned in the program included encouraging communication activities, developing potential tourism places and products; the local provinces reopened tourism activities, ensuring security against epidemic 19 and a willingness to attract tourists. Moreover, the tourism industry developed and deployed incentive packages such as introducing packages with promise of suppliers about price and service according to the package tour or partial services. However, Sapa was affected by the Covid 19. The number of tourist has a sharp decrease. In my opinion, these methods mentioned above are really necessary, which helped tourism overcome this difficult situation.

As stated by Vietnam tourism development scheme to 2020 and the vision to 2030 on January 22, 2013 clearly defines Vietnam as having 7 tourist areas with 24 tourist centers.

Northern mountainous region of Vietnam included 14 provinces of Hoa Binh, Thai Nguyen, Son La, Lao Cai, Tuyen Quang, Ha Giang, Bac Kan, Dien Bien, Lai Chau, Yen Bai, Phu Tho, Cao Bang, Lang Son and Bac Giang (Vietnam tourism development plan to 2020, vision to 2030, 2013). 
International Journal of Economics, Business and Management Research

Vol. 6, No.02; 2022

ISSN: $2456-7760$

This region had 5 key tourist destinations:

$>$ Son La - Dien Bien: in association with Moc Chau, Son La lake, Tay Trang international border gate, historical relics of Dien Bien Phu and Muong Phang.

$>$ Lao Cai is connected to Lao Cai international border gate, Sa Pa, Phan Xi Pang and Hoang Lien National Parks.

$>$ Phu Tho is associated with Hung Temple Festival and the system of relics of Hung Vuong era, traveling to Thac Ba lake.

$>$ Thai Nguyen - Lang Son is associated with Coc lake, ATK Dinh Hoa relics, Tan Trao, Dong Dang border gate economic zone, Mau Son resort.

$>\mathrm{Ha}$ Giang is associated with the Dong Van Plateau Global Geopark, Meo Vac, Ma Pi Leng and $\mathrm{Na}$ Hang landscapes.

In term of this study, the author choose Lao Cai province (Sapa destination) which has a lot of strategic advantages for ecotourism development.

Sa Pa (Lao Cai) was selected by the travel site Trips to Discover (USA) as one of the 14 Asia amazing destinations in early July 2020. Therefore, analysis of factors affecting tourists' satisfaction and behavioral intention is important for tourism management (Torres-Sovero et al, 2012). The focus is how to welcome more visitors to this area, which led the author to conduct this topic. The analysis of satisfaction and behavioral intention of tourists in ecotourism sites in Sapa (Lao Cai province) is a great help in order that Sapa can overcome this challenging period.

Behavioral intention can be explained by both satisfaction (Petrick and Backman, 2002). Repurchase behavior was influenced by consumer satisfaction (Anderson and Sullivan, 1993).

Standard and criterion for endurable ecotourism in KBR Region, Developed at Yuksam, West Sikkim was shown that Factors which influenced tourist's satisfaction involved preserving of Ecosystem Health; preservation of traditional value; facilitating environment and cultivating environmental awareness.

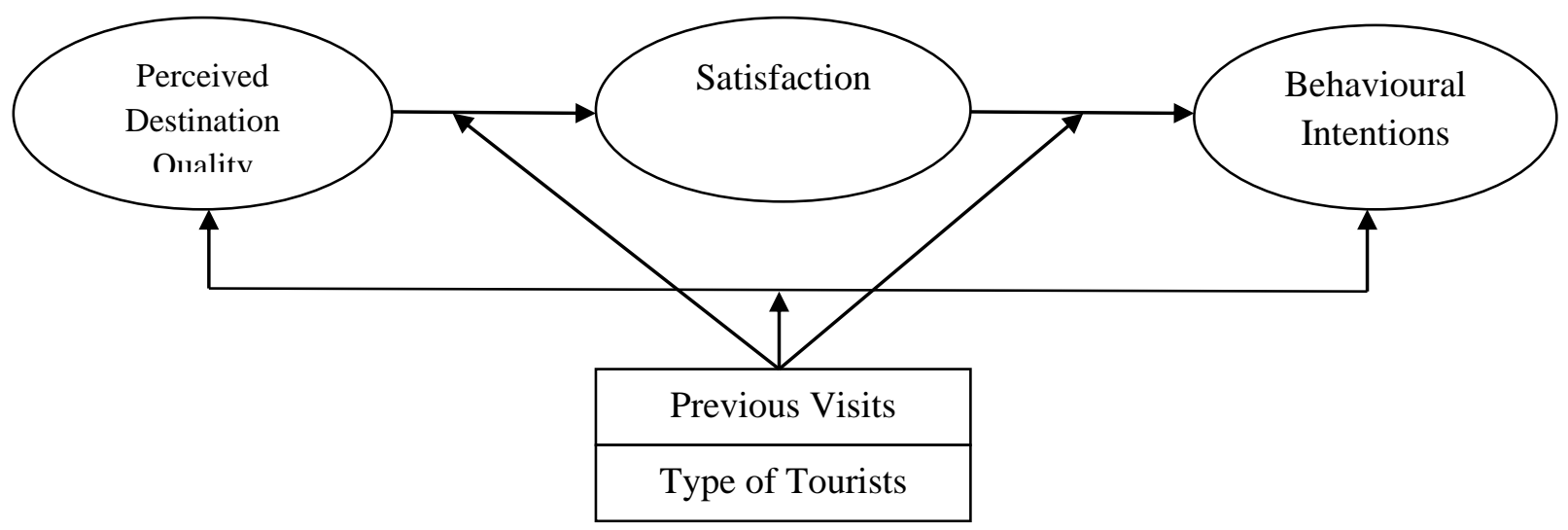

Figure 1: Perceivied destination quality and behavioural intentions of rural tourism destinations in Malaysia

(Source: Nairet.al., 2015) 
Vol. 6, No.02; 2022

ISSN: 2456-7760

Nair, Hussain, Chiun, Ragavan, Rajaratnam, Sharif \& Munikrishnan beleived that Destination quality will result in Customer Satisfaction. In addition, Satisfaction had a direct influence on behavioral intentions (Nair, Hussain, Chiun, Ragavan, Rajaratnam, Sharif \& Munikrishnan, 2015).

\section{Satisfaction}

In the tourism context, the level of traveller satisfaction the "positivity level" is triggered by the destination experience with a tour or sightseeing places, which was the consequence of many views such as their perception of the experienced services as well as their expectations (Pratusingsih et al, 2014).

Destination satisfaction was recognized as the degree to which the traveller assessed the destination's characteristics exceeded their expectations about those features (Tribe and Snaith, 1998). Tourism satisfaction was also defined as the degree of satisfaction to tourists' expectations (Akama and Kieti, 2003).

\section{Perceptions}

Perceptions were important in understanding the people and behavior of travellers (Fayed, Wafik \& Gerges, 2016)

Bolton \& Drew asserted that For the same product, not only monetary factors, but also other factors, such as time, personal preference, symbolism and impact quality. Perception of perceived value could vary between individuals (Bolton \& Drew, 1991).

\section{Behavioral intentions}

Post-purchase behavioral intention could be used to predict whether a customer could be a longterm customer and brought a steady profit to the business (Chen and Chen, 2010).

Antecedents Model of Service Quality

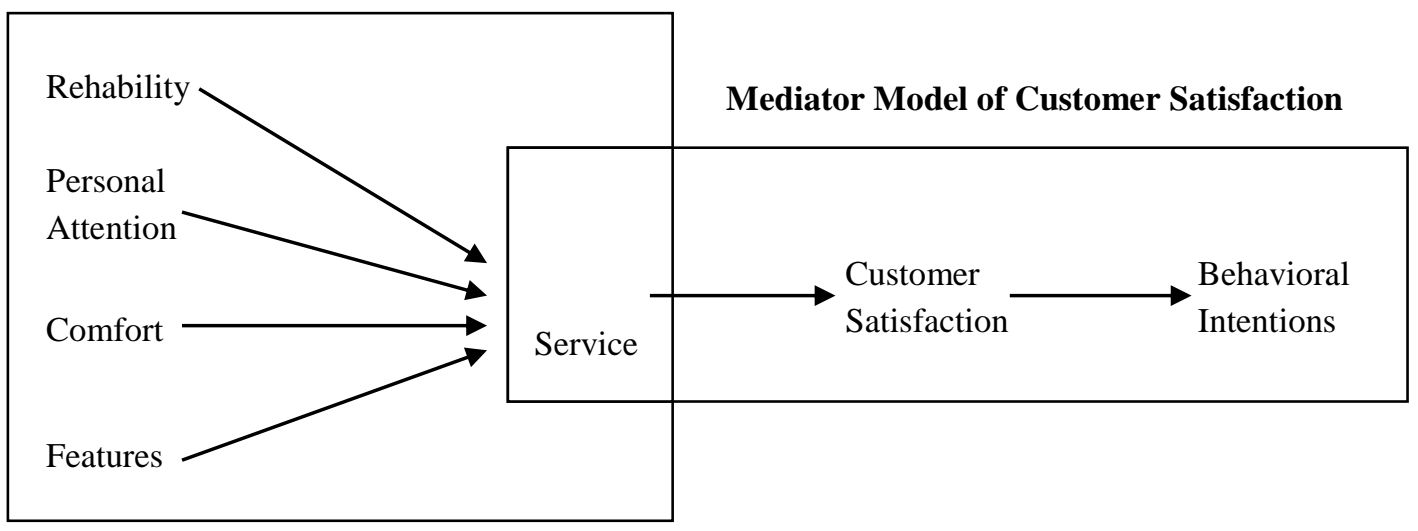

Figure 2: The premise and intermediate model

(Source: Dabholkar at el, 2000) 


\section{International Journal of Economics, Business and Management Research}

Vol. 6, No.02; 2022

ISSN: 2456-7760

This figure was seen as comprehensive in terms of service quality. In addition to providing a deeper understanding of service quality concepts, the model considers the prerequisite, mediation, and outcome of service quality as the factors that are considered prerequisites. better service quality and the relationship between service quality and customer satisfaction and customer behavioral intents. The framework of Dabholkar et al focuses on the problem: What is the role of actual buying behavior and acquisition intent in impacting customer assessment of service quality and their satisfaction? What are the premisees of customer satisfaction as it relates to the premise of service quality?

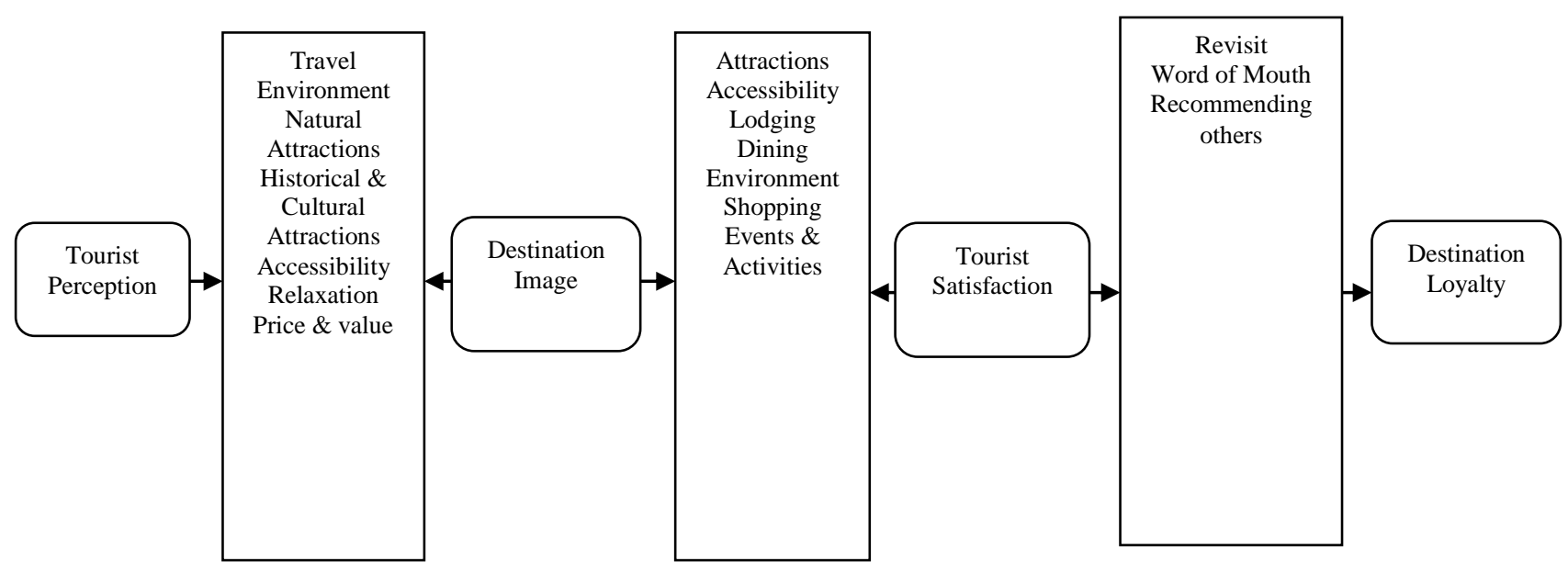

Figure 3: Impacts of Tourist Perception, Destination Image and Tourist satisfaction on Destination Loyalty

(Rajesh, 2013)

Rajesh found that the antecedent of Destination loyalty that indicated an intent to acquire or revisit as well as conduct word of mouth was influenced by Tourist Perception, Destination Image and Tourist satisfaction. The factors involved in Tourist Perception was Travel Environment; Natural attractions; Historical \& Cultural Attraction; Accessibility, Relaxation; and Price \& value (Rajesh, 2013).

D. Buhalis proposed attraction, accessibility, amenities, the available ancillary packages, activities and services were the six key components of a destination (Buhalis, 2000).

\section{Hols at model}

Tribe and Snaithe mentioned that three main research tools have been developed to analyze the concepts of quality and consumer satisfaction. Tribe and Snaith developed a fourth tool called HOLSAT (holiday satisfaction).

It could be seen that the HOLSAT model of Tribe and Snaith emphasized the factor that meets tourists' satisfaction with the quality of the service received. The model emphasized on tourists' evaluation of how well the service performance meets the expectations of the tourist or the beneficiary. The HOLSAT model had emphasized the satisfaction factor of tourists, the main 
service object of the tourism industry, so that changes could be made, recommendations and policies were appropriate for tourism development (Tribe and Snaithe, 1998).

The development of ecotourism

Table 1. The development of ecotourism

\begin{tabular}{|l|l|l|l|}
\hline $\mathbf{1 9 6 0 - 1 9 7 0}$ & \multicolumn{1}{|c|}{$\mathbf{1 9 7 0 - 1 9 8 0 s}$} & \multicolumn{1}{|c|}{ 1990s } & \multicolumn{2}{|c|}{ From 2000 to present } \\
\hline $\begin{array}{l}\text { Ecological } \\
\text { tourism }\end{array}$ & $\begin{array}{l}\text { Pure Ecotourism/ } \\
\text { Nature tourism } \\
\text { (Hector, 1987) }\end{array}$ & $\begin{array}{l}\text { Ecotourism } \\
\text { "Contribute to } \\
\text { preserving the } \\
\text { natural and welfare } \\
\text { of the local people. } \\
\text { thembination of tourism } \\
\text { (Wood, 1991); } \\
\text { L.Hens, 1998) }\end{array}$ & $\begin{array}{l}\text { comomic development with } \\
\text { introduction of national beauty } \\
\text { as well as propaganda and } \\
\text { protection education, } \\
\text { sustainable development of } \\
\text { environment natural } \\
\text { resources" and nal } \\
\text { (Le Huy Ba, 2000) }\end{array}$ \\
\hline
\end{tabular}

(Source: This study)

In the first place, it is important to understand the development of ecotourism in general and in the Northern mountain region in particular in different periods, which is demonstrated in Table 1.

Antecedent variables

\begin{tabular}{|c|c|}
\hline $\begin{array}{ll} & \text { Personal Profile } \\
\text { - } & \text { Gender } \\
\text { - } & \text { Age } \\
\text { - } & \text { Tourist type } \\
\text { - } & \text { Marital status } \\
\text { - } & \text { Educational level } \\
\text { - } & \text { Occupation } \\
\text { - } & \text { Average monthly } \\
& \text { income }\end{array}$ & $\begin{array}{ll}\text { Influencing Factors } \\
\text { - } & \text { Eco-system health } \\
\text { - } & \text { Historical \& } \\
& \text { Cultural Attraction } \\
\text { - } & \text { Amenities } \\
\text { - } & \text { Accommodation } \\
\text { - } & \text { Food } \\
\text { - } & \text { Occupation } \\
\text { - } & \text { Safety \& Security }\end{array}$ \\
\hline
\end{tabular}

Dependent Variables

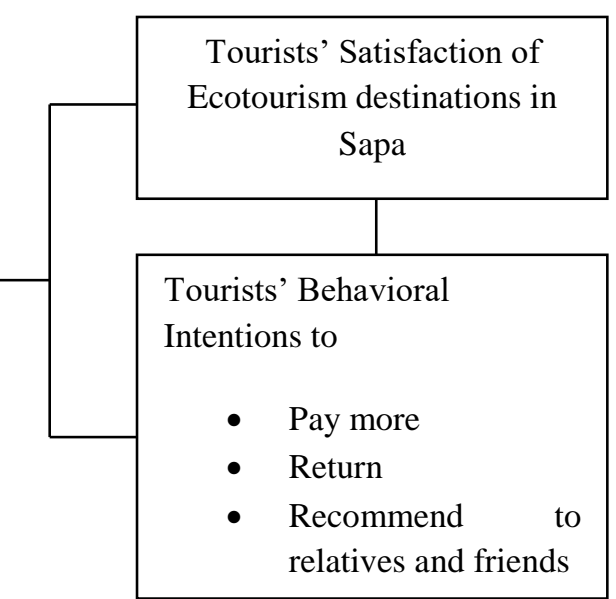

Figure 4. Proposed Conceptual Framework in this study

(Source: synthesized by the author)

The research's conceptual framework has 3 following components: 


\section{International Journal of Economics, Business and Management Research}

Vol. 6, No.02; 2022

ISSN: 2456-7760

The antecedent variable is personal outline of tourists who visited Ecotourism sites of Sapa, Lao Cai province in terms of age, marital status, gender, tourist type, educational level, monthly income and occupation.

The independent variables are factors affecting Tourists' satisfaction of Ecotourism destinations in Sapa, 7 main factors affecting Tourists' satisfaction of Ecotourism destinations identified such as Eco-system Health, Historical \& Cultural Attraction, Amenities, Accommodation, Food, Occupation and Safety \& Security.

The dependent variables are Tourist's Satisfaction and behavioral intentions at Ecotourism destinations in Sapa.

\section{Methods}

The key respondents of this study are domestic tourists visiting eco-tourism areas in Sapa (Lao Cai). Due to the translation of Covid 19 affecting the sampling process, the researcher had difficulty in calculating sample size. Therefore, it is impossible to identify a sampling frame and limited resources; the sample was selected according to the convenient method, one of several forms of non-probability sampling. According to the experience of researchers, if using the maximum suitable estimation method (ML estimation method), the minimum sample size should be from 100 to 150 (Hair et al., 1988). Hair, Anderson, Tatham and Black (1998) gave the suggestion for expected sample size. Roger (2006) showed his study about sample size that the minimum sample size applicable in practical studies is from 150-200.

In addition, the number of observed variables was supposed to be $1 / 5$ times the number of samples needed (Hoang Trong \& Chu Nguyen Ngoc; 2005). Thus, for convenience, the author uses this method to calculate the sample size for this study. In this research, the number of variables used is 50 , so the expected number of samples is at least 250 samples. However, to make the sample more general and practical, the author increased the sample size compared to the convention of $n=500$.

Due to financial ability and time limitation, the author collected evaluation of 500 domestic tourists traveling to five ecotourism sites of Sapa, which are famous tourist spots represent mountain ecosystems, mountain ecology, forest ecology, terraced field ecology, community village ecology, which are Hoang Lien park; Fanxipang mountain; CatCat village; Muong Hoa valley; Ham Rong mountain. There are also sites that are privately managed and managed by the state. For each site, the researcher will conduct a survey of 100 tourists.

Population, Sample Size and Sampling Technique

\section{Sampling Design}

Sample: mainly domestic tourists traveling to ecotourism sites of Sapa (Lao Cai province), they may be first time visitors to Sapa or they have been to Sapa before. They can be tourists in Lao Cai province or other provinces of Vietnam

$>$ The age: from 18 to over 60 (From 18 to 25 years old; From 26to 39 years old; From 40 
Vol. 6, No.02; 2022

ISSN: $2456-7760$

to 59 years old; Over 60 years old)

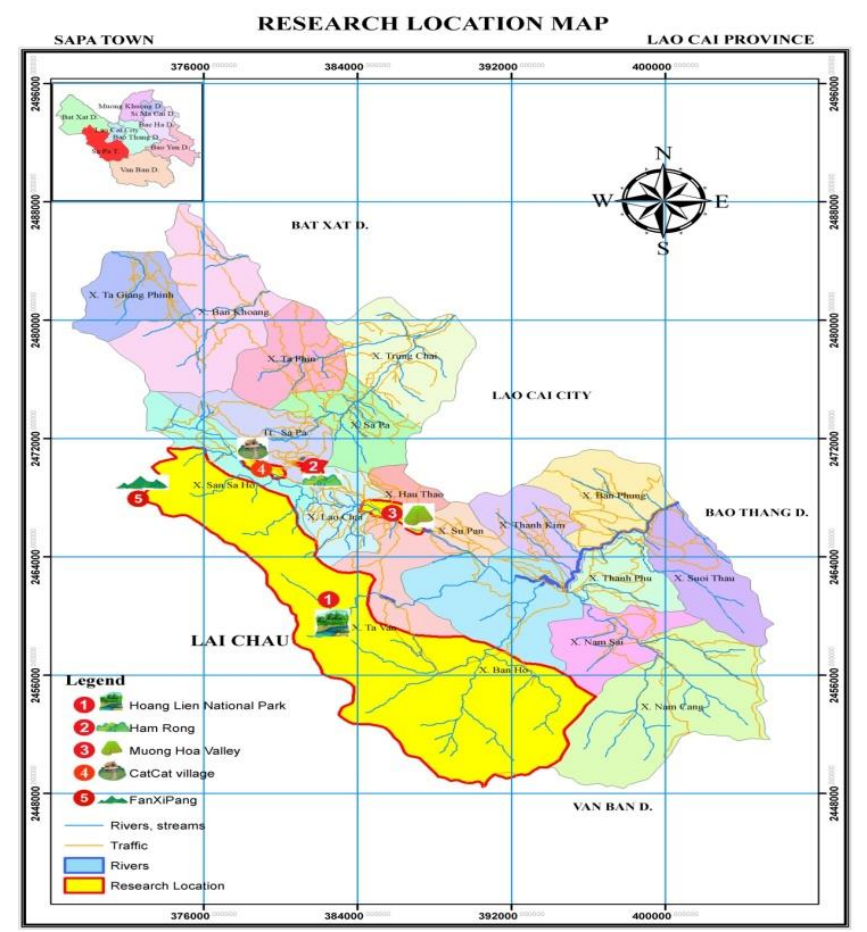

Figure 5: Places of data collection map designed by author Source: Sapa map

To do this research, the author built a questionnaire on the google form system and delivered to tourists through Internet by the following helps:

Firstly, the author needed assistance from travel agencies, hotels, and homestays in Sapa to ask them to distribute the questionnaire to guests who visited research sites.

Secondly, from the point of practical research, the researcher participated in tourism services which also sold travel packages to Sapa including round-trip passenger bus tickets and destination accommodation. In addition, the researcher also advised and sold travel tickets for travel companies to reach customers from all over Sapa.

Thirdly, the author also asked for the help from the alumni and students group of two universities, Thai Nguyen University branch in Lao Cai province and University of Economics and Business Administration in Thai Nguyen province;. Students who were born and grew up in Sapa or are working in the tourism industry in Sapa will assist in giving information to tourists regarding the survey instruments available on Internet.

Although the huge impact of the covid epidemic in 2020, the way to pick 100 respondents per location was completely random. Since the researcher selected local support students at the study sites, each group of students sent survey links to visitors during the study period because they 


\section{International Journal of Economics, Business and Management Research}

Vol. 6, No.02; 2022

ISSN: $2456-7760$

knew who came here. However some visitors were not eager to answer. The researcher also went directly to research destinations to understand the actual situation. However, it was difficult to capture the number of visitors because the number of visitors was heavily affected by the epidemic. In addition, the number of customers who bought tickets, transportation and accommodation package of the researcher during the combo business was also sent a survey link by the researcher to each random participant during that time.

\section{Methods of collecting and processing data secondary}

Secondary data in the document were collected from books, newspapers, magazines and on the internet. Data sourced from these materials were processed by comparison method, evaluation; analysis and synthesis to ensure counting validity and relevance to those data inherit.

\section{Methods of collecting and analyzing primary data}

The sampling locations were ecotourism sites in Sapa (Lao Cai).

SPSS software was used to process the questionnaire through the following methods: descriptive statistics (frequency and average), verification of the average of the two samples in pairs (MannWhitney U-test for two groups), assessing reliability of scales (Scale Reliability Analysis, analysis of correlation between two variables (using Spearman Rho), Kruskal Wallis H-test for three or more groups, and Exploratory Factor Analysis.

\section{The key variables for framework}

From the literature review and expert visit, the author found the key variables for the framework as below.

Table 2. Key variables for framework

\begin{tabular}{|l|l|l|}
\hline Key variables & Description & Source \\
\hline \multirow{4}{*}{$\begin{array}{l}\text { Tourist's } \\
\text { perception }\end{array}$} & Ecosystem health & $\begin{array}{l}\text { Expert visit; (Toudert and Bringas-Rábago; 2016); (Blas\& } \\
\text { Carvajal-Trujillo 2014); (Kumari, Tewari \& Inbakaran, 2006) }\end{array}$ \\
\cline { 2 - 3 } & $\begin{array}{l}\text { Historical \& cultural } \\
\text { attraction }\end{array}$ & Expert visit; (Dekhili \& Achabou, 2015); (Rajesh, 2013) \\
\cline { 2 - 3 } & Amenities & $\begin{array}{l}\text { Expert visit; (VNAT, 2013); (Toudert and Bringas-Rábago; } \\
\text { 2016); (Blas\& Carvajal-Trujillo 2014); (Rajesh, 2013) }\end{array}$ \\
\cline { 2 - 3 } & Accommodation & (Sukimanel al, 2013); (Lu \&Stepchenkova, 2012); \\
\cline { 2 - 3 } & Food & (Lu \&Stepchenkova, 2012); \\
\cline { 2 - 3 } & Safety and Security & (UNWTO, 1997); (Edgell et. al., 2008); (Tarlow, 2009) \\
\hline \multirow{2}{*}{$\begin{array}{l}\text { Tourist's } \\
\text { satisfaction }\end{array}$} & Tourist's satisfaction & $\begin{array}{l}\text { (Tribe and Snaith, 1998); (Pratminingsih et al, 2014); (Quintal \& } \\
\text { Polczynski, 2011) }\end{array}$ \\
\hline $\begin{array}{l}\text { Tourist's } \\
\text { behavioral } \\
\text { intention }\end{array}$ & Intention to pay more & $\begin{array}{l}\text { Expert visit; (Kotler et al; 2014);(Zeithaml, Berry and } \\
\text { Parasuraman, 1996) }\end{array}$ \\
\cline { 2 - 3 } & Intention to return & Expert visit; (Gao \& Lai; 2015); (Oliver, 2010) \\
\cline { 2 - 3 } & $\begin{array}{l}\text { Intention to introduce } \\
\text { to friends and relatives }\end{array}$ & $\begin{array}{l}\text { Expert visit; (Gao \& Lai; 2015); (Kotler et al; 2014); (Hui, Wan } \\
\text { \& Ho, 2007) }\end{array}$ \\
\hline
\end{tabular}

(Source: This study) 
International Journal of Economics, Business and Management Research

Vol. 6, No.02; 2022

ISSN: $2456-7760$

\section{Results}

Table 3. Demographic characteristics

\begin{tabular}{|c|c|c|c|}
\hline Items & Categories & Frequency & $\begin{array}{c}\text { Percentage } \\
\text { rates }(\%)\end{array}$ \\
\hline \multirow[t]{2}{*}{ Gender } & Male & 140 & 28 \\
\hline & Female & 360 & 72 \\
\hline \multirow[t]{5}{*}{ Age } & Below 18 & 30 & 6 \\
\hline & $18-25$ & 301 & 60,2 \\
\hline & $26-39$ & 102 & 20,4 \\
\hline & $40-59$ & 62 & 12,4 \\
\hline & Over 60 & 5 & 1,0 \\
\hline \multirow[t]{3}{*}{ Tourist type } & Tourist buys tour & 64 & 12,8 \\
\hline & $\begin{array}{l}\text { Tourist buys tourism package (involved in } \\
\text { transportation and accommodation) }\end{array}$ & 137 & 27,4 \\
\hline & Self-sufficient & 299 & 59,8 \\
\hline \multirow[t]{2}{*}{ Marital status } & Single & 340 & 68 \\
\hline & Married & 160 & 32 \\
\hline \multirow[t]{6}{*}{ Where are you from? } & Lao Cai province & 72 & 14,4 \\
\hline & Ha Noi & 134 & 26.8 \\
\hline & Ho Chi Minh city & 25 & 5 \\
\hline & Da Nang city & 27 & 5,4 \\
\hline & Thai Nguyen/ Bac Giang/ Bac Ninh (provinces) & 226 & 45,2 \\
\hline & Other provinces .................. & 16 & 3,2 \\
\hline \multirow[t]{3}{*}{ Education level } & High school graduate & 215 & 43 \\
\hline & College graduate & 143 & 28,6 \\
\hline & Postgraduate & 142 & 28,4 \\
\hline \multirow[t]{2}{*}{ Occupation } & Student & 235 & 47 \\
\hline & Worker & 64 & 12,8 \\
\hline
\end{tabular}


International Journal of Economics, Business and Management Research

Vol. 6, No.02; 2022

ISSN: $2456-7760$

\begin{tabular}{|c|c|c|c|}
\hline \multirow[t]{6}{*}{ Items } & Categories & Frequency & $\begin{array}{c}\text { Percentage } \\
\text { rates }(\%)\end{array}$ \\
\hline & Teacher/ Lecturer & 99 & 19,8 \\
\hline & Business & 34 & 6,8 \\
\hline & Housewife & 12 & 2,4 \\
\hline & Staff & 53 & 10,6 \\
\hline & 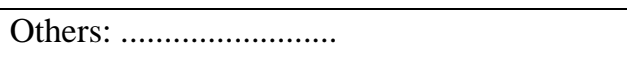 & 3 & 6 \\
\hline \multirow{6}{*}{$\begin{array}{l}\text { Average } \\
\text { income/month }\end{array}$} & Less than 5 millions VND & 252 & 50,4 \\
\hline & 5 millions VND - under 7 millions VND & 91 & 18,2 \\
\hline & 7 millions VND - under 10 millions VND & 89 & 17,8 \\
\hline & 10 millions VND - under 15 millions VND & 32 & 6,4 \\
\hline & 15 millions VND - under 20 millions VND & 26 & 5,2 \\
\hline & Over 20 millions VND & 10 & 2 \\
\hline \multirow{5}{*}{$\begin{array}{l}\text { Please list names of } \\
\text { ecotourism sites of } \\
\text { Sapa you have } \\
\text { travelled }\end{array}$} & Fansipan & 100 & 20 \\
\hline & Ham Rong mountain & 100 & 20 \\
\hline & Hoang Lien park & 100 & 20 \\
\hline & Cat Cat village & 100 & 20 \\
\hline & Muong Hoa valley & 100 & 20 \\
\hline
\end{tabular}

(Source: SPSS analysis in this study)

The author analyzed demographic characteristics such as gender, age, tourist type, marital status, occupation, hometown, education level, income ... The data was shown abow. 
International Journal of Economics, Business and Management Research

Vol. 6, No.02; 2022

ISSN: $2456-7760$

Table 4. Descriptive statistics of observed variables

\begin{tabular}{|c|c|c|}
\hline Items & Mean & $\mathbf{N}$ \\
\hline \multicolumn{3}{|l|}{ B.B1.1. Ecosystem Health } \\
\hline EH1. Wildlife sighting and sighting of avifauna & 3,14 & 500 \\
\hline EH2. Abundance of Fresh water sources & 3,52 & 500 \\
\hline EH3. Original status of the forest/ terraces/ hill / waterfall/ siver & 3,21 & 500 \\
\hline EH4. Fresh air / natural atmosphere & 3,95 & 500 \\
\hline EH5. Conservation of endangered /threatened plants/animals & 3,7 & 500 \\
\hline Mean total score & 3,5 & \\
\hline \multicolumn{3}{|l|}{ B.B1.2. Historical \& cultural attraction } \\
\hline HCA1. Availability of traditional/local food, handicrafts & 3,72 & 500 \\
\hline HCA2. The activities like monastic dances, ethnic festivals etc & 3,68 & 500 \\
\hline HCA3. The local people are hospitable and friendly & 3,38 & 500 \\
\hline HCA4. There are many historical place & 3,01 & 500 \\
\hline Mean total score & 3,45 & \\
\hline \multicolumn{3}{|l|}{ B.B1.3. Amenities } \\
\hline AM1. Easy traffic & 3,29 & 500 \\
\hline AM2. Safe and stable electricity and water supply system & 3,58 & 500 \\
\hline AM3. Many shopping stores & 3,61 & 500 \\
\hline AM4. Convenient communication/ wifi & 3,61 & 500 \\
\hline AM5. Clear signs and explanations about the tourist attraction; & 3,61 & \\
\hline Mean total score & 3.54 & \\
\hline \multicolumn{3}{|l|}{ B.B1.4. Accommodation } \\
\hline $\begin{array}{l}\text { AC1. The quality and service of the hotels/motels meet the } \\
\text { requirements }\end{array}$ & 3,18 & 500 \\
\hline AC2. The reasonable price for accommodation services & 3,01 & 500 \\
\hline AC3. Professional staff & 3,28 & 500 \\
\hline Mean total score & 3.16 & \\
\hline \multicolumn{3}{|l|}{ B1.5. Food } \\
\hline F1. The food tastes delicious & 3,57 & 500 \\
\hline F2. The dishes are good quality and hygienic food & 3,51 & 500 \\
\hline F3. The prices of the dishes are reasonable & 3,08 & 500 \\
\hline F4. The dishes are plentiful and varied & 3,61 & 500 \\
\hline Mean total score & 3,44 & \\
\hline \multicolumn{3}{|l|}{ B1.6. Safety and Security } \\
\hline SS1. There is no threat of terrorism & 3,61 & 500 \\
\hline $\begin{array}{l}\text { SS2. There is no situation of robbery, pickpockets/ common crime and } \\
\text { violence }\end{array}$ & 3,41 & 500 \\
\hline SS3. Police/ guard service & 3,41 & 500 \\
\hline Mean total score & 3,48 & \\
\hline
\end{tabular}

(Source: This study)

Table 4 showed that most of the variables were above average satisfaction values, ranging from 3.01 to 3.95. Specifically, three variables had a high mean value above 3.7: EH4. Fresh 
International Journal of Economics, Business and Management Research

Vol. 6, No.02; 2022

ISSN: $2456-7760$

air/natural atmosphere (3.95); HCA1. Availability of traditional/local food, handicrafts (3.72); EH5. Conservation of endangered/threatened plants/animals (3.7).

Table 5. Descriptive statistics of Tourists' overall satisfaction variables

\begin{tabular}{llc}
\hline Items & Mean & N \\
\hline B.B2. Tourists' overall satisfaction & & \\
TS1. I really love travelling to ecotourism sites of Sapa & 3,61 & 500 \\
TS2. I am pleased with my decision to travel to ecotourism sites of Sapa & 3,65 & 500 \\
TS3. Sapa is more amazing than I thought & 3,12 & 500 \\
TS4. This is the experience I would like to have & 3,61 & 500 \\
TS5. This trip is one of my best choice & 3,5 & 500 \\
$\quad$ Meantotal score & $\mathbf{3 , 5}$ & \\
\hline
\end{tabular}

(Source: This study)

As can be seen from Table 5, the overall mean of visitor satisfaction was quite high, ranging from 3.12 to 3.65. This has shown that domestic tourists were satisfied when traveling in Sapa's eco-spots in Lao Cai. Highest variables were TS2. I am pleased with my decision to travel to ecotourism sites of Sapa $(3,65)$; TS4. This is the experience I would like to have (3.61); TS1. I really love traveling to ecotourism sites of Sapa (3.61); TS5. This trip is one of my best choice (3.5) Besides, the lowest variable was TS3. Sapa is more amazing than I thought $(3,12)$ which showed that satisfaction was not at the highest level.

Table 6. Descriptive statistics of Behavioral intention variables

\begin{tabular}{lll}
\hline Items & Mean & N \\
\hline B.B3.1 Intention to return & & \\
IR1. I will return to ecotourism sites of Sapa in the future. & 3,56 & 500 \\
IR2. If I have a chance, I will choose ecotourism sites of Sapa again & 3,55 & 500 \\
IR3. I want to return to ecotourism sites of Sapa many times in my life & 3,43 & 500 \\
$\quad$ Mean total score & $\mathbf{3 , 5 1}$ & \\
\hline B.B3.2. Intention to pay more & 3,55 & 500 \\
IPM1. I am willing to pay more for my trip & 3,67 & 500 \\
IPM2. I intent to buy more next trip in Sapa & 3.39 & 500 \\
IPM3. I will purchase more if I have a chance & $\mathbf{3 , 2 5}$ & \\
$\quad$ Mean total score & 3.61 & 500 \\
\hline B.B3.3. Intention to introduce to friends and relatives & 3.42 & 500 \\
I2FR1. I will recommend my visit to other people & 3.42 \\
I2FR2. I will introduce ecotourism sites of Sapa to others & 500 \\
I2FR3. I will support my family and friends' trip to ecotourism sites of Sapa & $\mathbf{3 . 6 2}$ \\
$\quad$ Mean total score & \\
\hline Source: This Study)
\end{tabular}

(Source: This study)

According to Table 6, we saw that the mean values of behavioral intention variables were quite high, ranging from 3.37 to 3.63 . The highest were the variables such as IR2. If I have a chance, I will choose ecotourism sites of Sapa again $(3,6)$; IR1. I will return to ecotourism sites of Sapa in the future. (3.58); Next variables were I2FR1. I will recommend my visit to other people (3.61); 


\section{International Journal of Economics, Business and Management Research}

Vol. 6, No.02; 2022

ISSN: 2456-7760

I2FR2. I will introduce ecotourism sites of Sapa to others (3.61); I2FR3. I will support my family and friends' trip to ecotourism sites of Sapa (3.61); IR3. I want to return to ecotourism sites of Sapa many times in my life $(3,46)$. The lowest variables were the variables belonging to B3.2. Intention to pay more (Mean total score $=3.4$ ). Specifically, IPM1. I am willing to pay more for my trip $(3,35) ;$ IPM2. I intent to buy more next trip in Sapa $(3,39)$; IPM3. I will purchase more if I have a chance (3.01). This showed that the tendency of tourists to spend extra money when traveling at ecotourism destinations in Sapa was not appreciated.

The results of EFA analysis included two dependent variables such as tourists/ overall satisfaction with four observed variables, and tourists' behavioral intention including Intetion to return and recommend with 6 observed variables and Intention to pay more with 3 observed variables. Besides, there were three independent variables including (1) Accommodation, food, people, safe and security (AFPSS) with 10 observed variables, (2) Ecosystem health and cultural attraction (EHCA) with six observed variables, (3) Amenities (AM) with 5 observed variables, the adjusted research model is presented as follows.

The hypotheses are expressed bellowed:

$\mathrm{H}_{01}$ : There is not a difference in factors influencing tourist satisfaction according to profile of tourists.

$\mathrm{H}_{02}$ :There are not differences in factors that significantly influence the tourists' satisfaction of eco-tourism destinations Sapa as perceived by the respondents

$\mathrm{H}_{03}$ : There is not a difference in factors significant influence of tourist's satisfaction on the behavioral intentions of tourists to pay more, to return, and to recommend to friends and relatives

Since the population is non propbalistic based on the way of choosing number of sample and data is not normally distributed according to normal distribution test, parametric test statistic (such as t-test, ANOVA, and Pearson'sr.) was not used in this study. Non parametric test was used such as Mann-Whitney U-test for two groups (instead of t-test), Kruskal Wallis H-test for three or more groups (instead of ANOVA), and Spearman Rho (instead of Pearson's $r$.)

According to the exploratory factor analysis results of EFA, three independent variables were denoted from AFPSS including SS1, AC3, SS3, SS2, AC1, AC2, HCA3, F1, F2, and F4; EHCA including EH4, EH3, EH1, HCA2, HCA1, and EH5.; AM including AM4, AM3, AM5, AM2 and AM1; used to analyze the correlation with the dependent variable was tourists' satisfaction, denoted TS, including TS1, TS2, TS4, and TS5. In this study, the analysis of Spearman correlation coefficient was used to determine how the three factors above had an important influence on the satisfaction of domestic tourists at ecotourism destinations in Sapa. 
International Journal of Economics, Business and Management Research

Vol. 6, No.02; 2022

ISSN: $2456-7760$

Table 7. Correlation coefficient

\begin{tabular}{|l|l|l|l|l|l|}
\hline Item & AM & EHCA & AFPSS & TS \\
\hline \multirow{4}{*}{ Spearman's rho } & AM & 1,000 & $0,644^{* *}$ & $0,613^{* *}$ & $0,505^{* *}$ \\
\cline { 2 - 7 } & EHCA & $0,644^{* *}$ & 1,000 & $0,660^{* *}$ & $0,560^{* *}$ \\
\cline { 2 - 7 } & AFPS & $0,613^{* *}$ & $0,660^{* *}$ & 1,000 & $0,726^{* *}$ \\
\cline { 2 - 7 } & TS & $0,505^{* *}$ & $0,560^{* *}$ & $0,726^{* *}$ & 1,000 \\
\hline
\end{tabular}

**. Correlation is significant at the 0.01 level (2-tailed).

(Source: Processed by SPSS 20)

Through the above analysis in table 7, the variables satisfied the conditions for the correlation between the dependent variable TS (Tourist's satisfaction) and the independent variable: AFPSS (Accommodation, food, people, safe and security); EHCA (Ecosystem health and cultural attraction) and AM (Amenities)

Table 8. Correlation coefficient

\begin{tabular}{|l|l|l|l|l|}
\hline \multicolumn{2}{|c|}{ Item } & TS & IRR & IPM \\
\hline \multirow{3}{*}{ Spearman's rho } & TS & 1,000 & $0,726^{* *}$ & $0,197^{* *}$ \\
\cline { 2 - 6 } & IRR & $0,726^{* *}$ & 1,000 & $0,205^{* *}$ \\
\cline { 2 - 6 } & IPM & $0,197^{* *}$ & $0,205^{* *}$ & 1,000 \\
\hline
\end{tabular}

**. Correlation is significant at the 0.01 level (2-tailed).

(Source: Processed by SPSS 20)

Based on analysis result of table 8 , the variables all satisfy the conditions for the correlation between the variables TS (Tourist's satisfaction) and IRR (Intention to return and recommend); and IPM (Intention to pay more)

To test the satisfaction among tourists in AFPSS (including SS1, AC3, SS3, SS2, AC1, AC2, HCA3, F1, F2, and F4); EHCA (including EH4, EH3, EH1, HCA2, HCA1, and EH5); AM (including AM4, AM3, AM5, AM2 and AM1); We used test on Kruskal-Wallis analysis

\section{Discussion}

The results showed that domestic tourists appreciated the ecosystem health, in which the element of enjoying the fresh, natural atmosphere and the protection of endangered /threatened animals and plants was highly valued. Besides, traditional local products and dishes were also one of the important factors that were well appreciated by tourists, it could be said that the unique factor of indigenous traditions was strength of Sapa. Factors in the visitor satisfaction range above 3.4 were HCA2. The activities like monastic dances, ethnic festivals etc (3.68); F4. The dishes are 


\section{International Journal of Economics, Business and Management Research}

Vol. 6, No.02; 2022

ISSN: $2456-7760$

plentiful and varied (3,61); AM4. Convenient communication/wifi (3.61); SS1. There is no threat of terrorism (3.61); AM5. Clear signs and explanations about the tourist attraction $(3,61)$; Many shopping stores $(3,61) ;$ AM2. Safe and stable electricity and water supply system $(3,58) ; \mathrm{F} 1$. The food tastes delicious (3,57); AM3. EH2. Abundance of Fresh water sources $(3,52) ;$ F2. The dishes are good quality and hygienic food $(3,51)$; SS2. There is no situation of robbery, pickpockets/ common crime and violence $(3,41)$ and SS3. Police/guard service $(3,41)$, which was the particular concern of most visitors in terms of wifi conditions, signage, delicious food, local shops, clean water, system electricity and water systems, ensuring safety and security. Besides, the richness and diversity of traditional folk dances and ethnic festivals had created a great attraction for tourists; In addition, the variable with the lowest mean value (below 3.4) were AM1. HCA3. The local people are hospitable and friendly (3.38); Easy traffic (3.29); HCA4. There are many historical place $(3,01)$; EH3. Original status of the forest/ terraces/ hill/ waterfall/siver $(3,21)$; EH1. Wildlife sighting and sighting of avifauna $(3,14)$; AC1. The quality and service of the hotels/motels meet the requirements $(3,18)$; AC2. The reasonable price for accommodation services (3.01); AC3. Professional staff (3.28); F3. The prices of the dishes are reasonable (3.08); The fact that the above factors were not highly appreciated by tourists because the means of transport were actually quite easy and convenient in Sapa, but since the bus station was moved outside the central area, for those who travelled by themselves. they had to walk quite a distance or had to take a taxi for a short distance, or had to take a carpool instead of the transportation that took them to their accommodation; Local people were quite enthusiastic and hospitable, but some local people, especially children selling street food, enticing customers, taking advantage of the compassion of customers to sell goods also created a bad impression about the people here in visitors' hearts. Modern and traditional tourist attractions sprang up quite a lot, but not really many historical tourist attractions; the pristine condition was not appreciated because Sapa has undergone a lot of renovation, losing its inherent natural features, instead of commercialization. Tourists coming here also did not have many opportunities to see birds and wildlife; The factors of accommodation were not appreciated due to high prices and unprofessional service quality. It could be said that the accommodation facilities and hotels of Sapa were not really worthy of the name and star ranking, not according to international or domestic standards but using local standards; Diverse dishes but expensive here.

Regarding the scale system, the scales measuring the components affecting the satisfaction of tourists after the proposal had achieved the reliability and the allowable value. The research results of Cronbach Alpha coefficient of the scale of independent components and dependent components (except for variables HCA4, F3 and TS3) had the reliability greater than 0,7 and less than 0,95 . Thus, the scale designed in the research was statistically significant and achieved the necessary reliability coefficient. 


\section{International Journal of Economics, Business and Management Research}

Vol. 6, No.02; 2022

ISSN: 2456-7760

Regarding the exploratory factor analysis study of EFA with 22 observed variables of the independent component and 13 observed variables of the satisfaction scale component, the visitor's behavioral intention (both with factor loading coefficients greater than 0.5). The analysis results show that, after removing an observed variable (EH2), three factors were extracted and the dependent factors all reached the required value and were statistically significant.

Regarding Kruskal Wallis H-test, according to test statistics in tables, Chi-Square = looking up the normal distribution table, it was statistically significant; Statistical significance level $\mathrm{p}<$ 0.05 , which meant that we rejected $\mathrm{H}_{02}, \mathrm{H}_{03}$ and accepted $\mathrm{H}_{2}, \mathrm{H}_{3}$.

$\mathrm{H}_{2}$ : There are not differences in factors that significantly influence the tourists' satisfaction of eco-tourism destinations Sapa as perceived by the respondents

$\mathrm{H}_{3}$ : There is not a difference in factors significant influence of tourist's satisfaction on the behavioral intentions of tourists to pay more, to return, and to recommend to friends and relatives Regarding $\mathrm{H}_{01}$ : the comparison of tourists' satisfaction according to individual characteristics, based on the analysis results of Kruskal Wallis H-test and Mann-Whitney U-test, there were differences in satisfaction in age groups, gender groups, group of educational level, group of occupation, and group of tourist type. In addition, there was no difference in average income; the times tourists visited ecotourism sites of Sapa; the reasons to explain why tourists visited ecotourism sites of Sapa; the ways tourists get information about traveling; marital status.

\section{Conclusion}

This study contributes to proposing a scale system for factors studying visitors' satisfaction with an ecotourism destination and their behavioral intentions. The study will benefit tourism company or agencies; local government; researchers; tourists; local people; and nature environment. The study recommends the following policy recommendations to improve the service of Eco tourism destinations in Sapa: Policy recommendation about Ecosystem health and cultural attraction; Policy recommendation about Amenities; Policy recommendation about Accommodation, food, people, safe and security; And some other policy recommendations: Market orientation of domestic tourists; Business measures to prevent covid; Measures to stimulate tourism; and Developing eco-tourism in association with traditional craft villages to attract tourists

The research scope of the topic is limited in the area of some eco-tourism spots of Sapa in Lao Cai province such as Ham Rong mountain, Hoang Lien National Park, Fansipan mountain, Muong Hoa valley and Cat Cat village. The respondents are limited in domestic tourists traveling to ecotourism sites of Sapa. The results of the study will be the suggestion for the upcoming studies on visitors' satisfaction and intentional behavior when traveling in ecotourism destinations in other areas.

\section{Acknowledgments}

In order to complete this study, we are grateful to the lecturers of Central Philippine University and the lecturers of Thai Nguyen University of Economics and Business Administration for the comments and suggestions. In addition, we also received help with reports and data from 


\section{International Journal of Economics, Business and Management Research}

Vol. 6, No.02; 2022

ISSN: 2456-7760

information and culture office of Sapa district and Lao Cai Department of Culture, Sports and Tourism.

\section{References}

Akama, J. S., \& Kieti, D. M. (2003). Measuring tourist satisfaction with Kenya's wildlife safari: a case study of Tsavo West National Park. Tourism management, 24(1), 73-81.

Blas, S. S., \& Carvajal-Trujillo, E. (2014).Cruise passengers' experiences in a Mediterranean port of call.The case study of Valencia.Ocean\& coastal management, 102, 307-316.

Bolton, R. N. \& Drew, J. H. (1991), “A multistage model of customers' assessments of service quality and value", Journal of Consumer Research,17(March), 375-384.

Buhalis, D. (2000). Marketing the competitive destination of the future. Tourism Management, 21(1), 97-116.

Chan, S. (2016). Evaluation Of International Tourist Satisfaction In Weh Island Indonesia Using HOLSAT Model. International Journal of Scientific \& Technology Research, 5(05).

Chen, C., \& Chen, F. (2010). Experience Quality, Perceived Value, Satisfaction and Behavioral Intentions for Heritage Tourists. Tourism Management, 31(3), 29-35.

Chen, Y., Zhang, H., \& Qiu, L. (2013). A review on tourist satisfaction of tourism destinations. In LISS 2012 (pp. 593-604). Springer, Berlin, Heidelberg.

Curcio, C. A., Millican, C. L., Allen, K. A., \& Kalina, R. E. (1993). Aging of the human photoreceptor mosaic: evidence for selective vulnerability of rods in central retina. Investigative ophthalmology \& visual science, 34(12), 3278-3296.

David MC, Molina A, Esteban A (2007). An integrated model of price, satisfaction and loyalty: an empirical analysis in the service sector Journal. J. Prod. Brand Manage., 16(7): 459468

Dekhili, S., \& Achabou, M. A. (2015). The perception of ecotourism. Semantic profusion and tourists' expectations. RIMHE: Revue Interdisciplinaire Management, Home Entreprise, (5), 3-20.

Edgell, D.L., DelMastro A., M., Smith, G., Swanson, J.R., (2008). Tourism Policy and Planning: Yesterday, Today \& Tomorrow, Elsevier, Oxford

Fan, Z., Zhong, S., \& Zhang, W. (2012). Harmonious tourism environment and tourists perception: An empirical study of mountain-type world cultural heritage sites in China.

Fayed, H. A. K., Wafik, G. M., \& Gerges, N. W. (2016).The Impact of Motivations, Perceptions and Satisfaction on Tourists Loyalty. International Journal of Hospitality and Tourism Systems, 9(2), 14.

Gao, B. W., \& Lai, I. K. W. (2015). The effects of transaction-specific satisfactions and integrated satisfaction on customer loyalty. International Journal of Hospitality Management, 44, 38-47. 


\section{International Journal of Economics, Business and Management Research}

Vol. 6, No.02; 2022

ISSN: 2456-7760

Hair, J. F. J., Anderson, R. E., Tatham, R. L. \& Black, W. C. (1998), “Multivariate data analysis with readings", Englewood Cliffs, NJ: Prentice-Hall.

Hoàng Trọng, Chu Nguyễn Mộng Ngọc (2005), Phân tích dĩ liệu nghiên cúu với SPSS, NXB. Hồng Đức năm 2008.

Hui, T., Wan, D. \& Ho, A. (2007). Tourists' satisfaction, recommendation and revisiting Singapore. Tourism Management, 28(4), 965-975.

Hương, P. M., \& Huy, N. V. (2013). Local residents' attitudes and participation in tourism development in Ba Be National Park, Vietnam (Doctoral dissertation, Master thesis, Daegu University).

Khuong, M. N., \& Luan, P. D. (2015).Factors Affecting Tourists' Satisfaction towards Nam Cat Tien National Park, Vietnam-A Mediation Analysis of Perceived Value. International Journal of innovation, management and technology, 6(4), 238.

Kotler, P., Keller, K. L., Ancarani, F., \&Costabile, M. (2014). Marketing management 14/e: Pearson

Kumari, S., Tewari, R., \& Inbakaran, R. (2006). Sustainability Criteria and Indicators as Tools to Evaluate the Visitor Impact on Fragile Ecotourism Destinations: A Case Study of Kanchandzonga Biosphere Reserve, Sikkim, India. The Indian Geographical Journal, 80(1).

Lee, H. C., Pan, H. L., \& Chung, C. C. (2019).The Study of Destination Image, Service Quality, Satisfaction and Behavioral Intention-an Example of Dapeng Bay National Scenic Area.International Journal of Organizational Innovation (Online), 11(3), 25.

Long, P. H. (2007). Ecotourism Lecture. Hanoi National University.

Lu, W., \& Stepchenkova, S. (2012). Ecotourism experiences reported online: Classification of satisfaction attributes. Tourism Management, 33(3), 702-712.

Nair, V., Hussain, K., Chiun, L. M., Ragavan, M. N. A., Rajaratnam, S. D., Sharif, S. P., \& Munikrishnan, U. T. (2015). Destination quality and tourists' behavioural intentions: rural tourist destinations in Malaysia. Worldwide Hospitality and Tourism Themes.

Oliver, R. L. (2010). Satisfaction: A behavioral perspective on the consumer: ME sharpe

Pratminingsih, S., Rudatin, C., \&Rimenta, T. (2014). Roles of motivation and destination image in predicting tourist revisit intention: A case of Bandung-39. Indonesia. International Journal of Innovation, Management and Technology,5(1), 19-24.

Rajesh, R. (2013). Impact of tourist perceptions, destination image and tourist satisfaction on destination loyalty: a conceptual model. PASOS. Revista de Turismo y Patrimonio Cultural, 11(3), 67-78.

Sukiman, M. F., Omar, S. I., Muhibudin, M., Yussof, I., \& Mohamed, B. (2013).Tourist satisfaction as the key to destination survival in Pahang. Procedia-Social and Behavioral Sciences, 91, 78-87.

Tarlow, P.E., (2009). Tourism Safety and Security, in T. Jamal, M. Robinson (eds), The SAGE Handbook of Tourism Studies, SAGE Publications Ltd, London, pp. 464-480. 
Toudert, D., \& Bringas-Rábago, N. L. (2016). Impact of the destination image on cruise repeater's experience and intention at the visited port of call. Ocean \& Coastal Management, 130, 239-249.

Torres-Sovero, C., González, J. A., Martín-López, B., \& Kirkby, C. A. (2012). Social-ecological factors influencing tourist satisfaction in three ecotourism lodges in the southeastern Peruvian Amazon. Tourism Management, 33(3), 545-552.

Tribe, J., \& Snaith, T. (1998). From SERVQUAL to HOLSAT: holiday satisfaction in Varadero, Cuba. Tourism management, 19(1), 25-34.

UNWTO, (1996). Tourist Safety and Security. Practical Measures for Destinations, 179 p.

Zeithaml, V. A., Berry, L. L., \& Parasuraman, A. (1996). The behavioral consequences of service quality. Journal of marketing, 60(2), 31-46. 